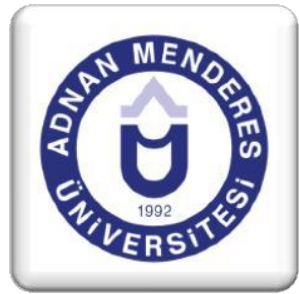

\section{Elektronik Belge Yönetim Sistemlerinin Genişletilmiş Teknoloji Kabul Modeli Temelinde Kullanımı: Ampirik Bir Değerlendirme $^{1}$}

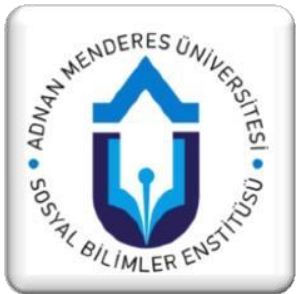

\title{
ÖZET
}

Gelişen bilgi teknolojileri ile birlikte kamu kurum ve kuruluşlarında gerek işlerin kapsamı gerekse iş yapma biçimleri değişmiştir. Buna örnek olarak resmi yazışmaların, dolaysıyla belgelerin elektronik ortamda hazırlanıp iletilmesi ve paylaşılması verilebilir. EBYS'nin önemi de bu noktada karşımıza çıkmaktadır. Sakarya Üniversitesinde bu kapsamda Eylül 2013 tarihinden itibaren EBYS uygulamasına geçilmiştir. Araştırmanın amac1, Sakarya Üniversitesi'nde kullanılmakta olan Elektronik Belge Yönetim Sisteminin (EBYS), çalışanlar tarafından benimsenmesine yönelik önemli noktaları açıklamaktır. Araştırma verileri akademik ve idari personel olarak görev yapan toplam 330 çalışandan toplanmıştır. Veriler SmartPLS programı ile analiz edilmiştir. Araştırma sonucunda EBYS'yi benimseme ve kullanımına etki eden en önemli faktörün uygulamaya dair algılanan fayda olduğu görülmüştür. İşle ilgililik faktörünün algılanan fayda üzerinde; algılanan fayda ve algılanan kullanım kolaylığının da niyet faktörü üzerinde olumlu bir etkiye sahip olduğu görülmüştür. Yalnızca deneyim faktörünün algılanan kullanım kolaylığı üzerinde herhangi bir olumlu etkisi doğrulanamamıştır.

Anahtar Kelimeler: EBYS, Teknoloji Kabul Modeli, Dijitalleştirme, Sakarya Üniversitesi

\section{Usage of Electronic Records Management Systems in the Basis of Extended Technology Acceptance Model: An Ampirical Evaluation}

\begin{abstract}
Along with the developing information technologies, the forms of doing business have changed in public institutions and organizations. As an example, official correspondences, so that records can be prepared and transmitted in electronic form and shared. The highlight of ERMS stands out at this point. In this context, Sakarya University has started the application of the ERMS in September 2013. The purpose of the research is to explain the important points about the adoption of ERMS, which is being used in Sakarya University. Datas are collected from 330 employees, who is working as academic and administrative staff. The datas were analyzed with the SmartPLS program. As a result of the research, it is seen that the most important factor affecting the adoption and use of ERMS is the perceived usefulness. It's seen that job relevance have positive effect on perceived usefulness, experience positive effect on perceived ease of use, perceived usefulness and perceived ease of use have positive effect on intention.
\end{abstract}

Keywords: ERMS, Technology Acceptance Model, Digitalization, Sakarya University

\footnotetext{
${ }^{1}$ Bu çalışma, Mehmet Oytun CİBAROĞLU tarafından Sakarya Üniversitesi İşletme Enstitüsü’nde Prof. Dr. Aykut Hamit TURAN danışmanlığında yürütülen "Elektronik Belge Yönetim Sisteminin Genişletilmiş Teknoloji Kabul Modeli Temelinde Benimsenmesi: Sakarya Üniversitesi Örneği” başlıklı yüksek lisans tezinden üretilmiştir.

${ }^{2}$ Sakarya Üniversitesi İşletme Enstitüsü Yönetim Bilişim Sistemleri Anabilim Dalı Yüksek Lisans Öğrencisi, oytun.cibaroglu@ogr.sakarya.edu.tr

${ }^{3}$ Prof. Dr., Sakarya Üniversitesi İşletme Fakültesi Yönetim Bilişim Sistemleri Bölümü, ahturan@sakarya.edu.tr
} 


\section{Giris}

Devlete ait olan kurum ve kuruluşlar, global ölçekteki gelişmelerden ötürü 20.yy'ın ikinci yarısından itibaren bilgi teknolojilerine yönelik projeler geliştirmeye başlamış, zaman içerisinde de internetin tabana doğru yayılması ile hizmetler bilgisayarlar aracılığı ile verilmeye başlanmıştır. Bu sürecin, kamu hizmetlerinin sunumunda köklü bir değişiklik meydana getirdiği kaçınılmazdır. Tamtürk'ün de belirttiği gibi (2017, s. 853) devletin elektronik hizmetler konusunda işlerlik kazanması, vatandaşlar ve işletmelerle interaktif ilişki içerisinde olmasını sağlamış ve kamu kurumlarının kendi içlerinde ve kurumlar arasındaki iletişimlerinde de zaman ve mekan farkı önemini yitirmiştir. Vatandaşlar da zaman ve mekandan bağımsız olarak işlem yaptıkları alanlarla ilgili daha hızlı ve doğru geribildirimler almıştır.

Kurumların gerek birbirleriyle gerekse kendi içerisindeki alt birimler ve vatandaşlarla haberleşmesi resmi yazılar aracılığı ile yapılmaktadır. Bu tür yazıların "Resmi Yazışmalarda Uygulanacak Esas ve Usuller Hakkında Yönetmelik" maddelerine göre belirli bir şekilde ve şablonda hazırlanması zorunludur. Zaman içerisinde bilgisayarlaşma oranının artması ve edevlet gerekliliklerinin yerine getirilmesi sonucunda yönetmelik 2015 yılında güncellenmiştir.

Önceleri fiziksel ortamda, daha sonraları da kelime işlemci paket programlar aracılığı ile oluşturulan resmi yazılar, bilişim alanındaki gelişmeler ile belge yönetim mekanizmasının mantıksal boyuta geçmesi neticesinde bilgisayar sistemlerine taşınmış; böylece Elektronik Belge Yönetimi (EBY) mantığı doğmuş; bu mantığın belirli bir sistem mimarisi içinde geliştirilmesi sonucu Elektronik Belge Yönetim Sistemi'nin (EBYS) oluşması sağlanmıştır. $\mathrm{Bu}$ sayede hizmetler ve işlemler sonucu oluşan tüm belgeler hızlı oluşturulma, doğru iletilme ve güvenli bir şekilde saklanma ile daha hızlı ve kolay erişilme olanağına kavuşmuştur.

Etkinlik ve verimlilik, kamu kurumlarını verdikleri hizmetlerde olmazsa olmaz bir unsur olarak karşımıza çıkmaktadır. Bu sebeple kamu kurum ve kuruluşları; daha güvenli, daha hızlı, daha doğru ve daha kısa sürede hizmet verebilmek için bilgi teknolojilerinden yararlanmak zorundadır. Resmi kuruluşların çeşitli mevzuatlar uyarınca ürettiği bilgi ve belgeler, yaptıkları işler ve gerçekleştirdikleri amaçları, yani var olma sebeplerini yazılı olarak resmi bir format içinde tutma ve bunları bir düzen ve bütünlük içinde saklama mecburiyeti vardır. Zamanla artan işlem yükü, her türlü bilgi ve belgenin belirli bir format içinde düzenlenmesini gerekli kılmıştır. Bunun nedeni de hizmetler ile ilgili tutulan kayıtlara, herhangi bir olumsuzluk durumunda kolayca ve hızlı bir şekilde ulaşılmak istenmesi ve böylece oluşabilecek sorunların kolaylıkla çözümünün sağlanmasıdır. EBYS uygulamaları ayrıca bürokrasinin hantallıktan kurtulması yolunda da önemli bir adım olmuştur.

\subsection{Elektronik Belge ve EBYS}

Teknolojik gelişmelerin belge yönetimi disiplinine uygulanmasından önce bu geliştirilen modeller, çoğunlukla geleneksel belge kayıt ortamlarına yönelik olmuştur. Belgelerin elektronik ortamda yönetimi fikri, özellikle 1980'li yılların sonundan itibaren BT alanındaki artan gelişmeler neticesinde oluşmuştur. Elektronik belgenin bir kavrama ve tanıma sahip olması gerekliliği, bu yönde çalışmaların artmasına ve hatta yasal düzenleme yolu ile belirli bir kapsama dahil edilmesi sonucunu doğurmuştur.

Birleşmiş Milletler Arşivler ve Belge Yönetimi Departmanı (UNARMS) (https://archives.un.org) elektronik belgeyi; elektronik sistemler aracıllı̆ıyla oluşturulan, iletilen ve saklanan; yapı (elektronik kaydın formatı ve eklere veya diğer ilgili belgelere olan bağlantılar), içerik (işlemin kanıtını taşıyan elektronik kayıt yapısındaki bilgiler) ve bağlam 
(kaynağın, ilişkili olduğu işlem, içerik oluşturucu, tarih, güvenlik ve erişim, dil, elden çıkarma, biçim vb. bakımından belgelenmesi ve normal olarak içerikten yapı içinde ayrılması) bileşenlerinden oluşan bir kayıtlar bütünü olarak tanımlamıştır.

$\mathrm{Bu}$ tanımdan hareketle bir elektronik belgenin dört bileşenden oluştuğu söylenebilir. Bunlar; içerik, yap1, bağlam ve sunumdur (Odabaş, 2008, s. 9; Cornu, 1997, s. 13).

Elektronik belgelerin sahip olması gereken özellikler ise International Organization for Standartization (ISO) 15489:1 (2001) standardında şu şekilde belirtilmiştir:

- Özgünlük: Belgelerin yetkisiz eklenmesine, silinmesine ve değiştirilmesine karş1 korunmasını sağlamak için ilgili prosedürler uygulanmalı ve belgelendirilmelidir.

- Güvenilirlik: Belgeler, ispat ettikleri işlemleri, aktiviteleri ya da gerçekleri tam ve doğru bir şekilde temsil ettiği sürece güvenilirdir.

- Bütünlük: Bir belgenin bütünlüğü, onun eksiksiz ve değiştirilmemiş olması anlamina gelmektedir.

- Kullanılabilirlik: Kullanılabilirlik, bir belgenin bulunabilir, erișilebilir, sunulabilir ve yorumlanabilir olmasıdır. Doğrudan bir iş faaliyetine bağlı olarak daha sonra gösterimi sağlanabilmelidir. Belgelerin bağlamsal zincirleri, bunları oluşturan ve kullanan işlemlerin anlaşılabilmesi için gereken bilgileri taşımalıdır.

Literatür incelendiğinde, EBYS'nin farklı tanımlara sahip olduğu görülmektedir. Hamza KANDUR tarafindan hazırlanan EBYS Kriterleri Referans Modeli (v2.0)'nde (2006, s. 7); "kurumların gündelik işlerini yerine getirirken oluşturdukları her türlü dokümantasyonun içerisinden, kurum aktivitelerinin delili olabilecek belgelerin ayılanarak bunların; içerik, format ve ilişkisel özelliklerini korumak ve bu belgeleri üretimden nihai tasfiyeye kadar olan süreç içerisinde yönetmek" olarak tanımlanmıștır. İskoçya Ulusal Arşivleri'nin tanımında ${ }^{4}$ ise daha çok elektronik arșivleme süreçlerine vurgu yapılmıștır. EBYS'nin sahip olması gereken özellikler ISO 15489:1'de (2001, s. 9) açıklanmıştır. Bunlar; güvenilirlik, bütünlük, uygunluk, kapsayıc1lık ve sistematikliktir.

EBYS, doğal olarak dokümanların yönetimi de kapsamaktadır. Bu tür sistemler bazı kaynaklarda "Elektronik Belge ve Doküman Yönetim Sistemi (EBDYS)" veya "Elektronik Doküman Yönetim Sistemi (EDYS)" olarak geçer. EDYS; MoReq2'de "elektronik dokümanlar üzerinde yönetim ve kontrol sağlamak için organizasyonlarda yaygın olarak kullanılan ve dokümanlar indeksleme, depolama, sürüm denetimi yapma ve masaüstü uygulamaları ile entegre etmek için kullanılan sistemler" olarak tanımlanmıştır. (European Commission, 2008, s. 109). EBYS ile EDYS arasında belirgin farklar mevcut olup bu farklar Moreq2'de belirtilmiştir.

\footnotetext{
${ }^{4}$ Belgeleri izlemek ve depolamak için tasarlanmış bir bilgisayar programı veya program dizisi olup, sınıflandırma şemaları içindeki belgelerin oluşturulmasını ve bakımını yönetmek, saklama ve imha programlarını uygulamak, erişimi ve kullanımı kontrol etmek için kullanılan kurumsal uygulamalar (https://www.nrscotland.gov.uk).
} 
Tablo 1. EDYS ile EBYS Arasındaki Farklar

\begin{tabular}{|l|l|}
\hline \multicolumn{1}{|c|}{ EDYS } & \multicolumn{1}{|c|}{ EBYS } \\
\hline Dokümanların değiştirilmesine izin verir. & Belgelerin değiştirilmesini önler. \\
\hline $\begin{array}{l}\text { Dokümanların çeşitli versiyonlarda olmasına izin } \\
\text { verir. }\end{array}$ & $\begin{array}{l}\text { Bir belgenin tek bir son sürümünün olmasına izin } \\
\text { verir. }\end{array}$ \\
\hline $\begin{array}{l}\text { Dokümanların, sahipleri tarafından silinmesine izin } \\
\text { verir. }\end{array}$ & $\begin{array}{l}\text { Tam anlamıyla kontrol edilebilen koşullar haricinde } \\
\text { belgelerin silinmesini önler. }\end{array}$ \\
\hline Saklama planları içerebilir. & Oldukça sıkı saklama kontrolleri içerir. \\
\hline $\begin{array}{l}\text { Kullanıcıların kontrolü altında olabilecek bir } \\
\text { doküman depolama altyapısı içerebilir. }\end{array}$ & $\begin{array}{l}\text { Yönetici yetkisi tarafından korunan sikı bir } \\
\text { sinıflandırma ve depolama şeması içermelidir. }\end{array}$ \\
\hline $\begin{array}{l}\text { Öncelikli olarak günlük devam eden rutin işlerdeki } \\
\text { dokümanların kullanımını desteklemek için } \\
\text { tasarlanmıştır. }\end{array}$ & $\begin{array}{l}\text { Günlük işleri destekleyebilir, fakat öncelikle } \\
\text { organizasyonun kanıtı olan belgeler için güvenli bir } \\
\text { depo olarak tasarlanmıştır. }\end{array}$ \\
\hline
\end{tabular}

Kaynak: European Commission (2008, s. 109)

Tablodan görüleceği üzere her ne kadar belge yönetim sistemleri, doküman yönetim sistemlerini kapsasa da özellikle içerik ve depolama yönlerinden kesin çizgilerle birbirinden ayrılır. Ayrıca EBYS, daha çok kurumsal yapılar için kullanıma daha uygunken, EDYS günlük işlerin daha çok önem arz ettiği organizasyonlar için uygundur.

\subsection{Türkiye'de Elektronik Belge Yönetimi Alanında Yapılan Çalışmalar}

Türkiye'de bu alanda yapılan çalışmalar, Avrupa Birliği'nin e-Avrupa projesine başlamasının bir etkisi olarak görülebilir. Ülkemizde e-devlet çalışmaları önceliklendirilmiş olup, bu çalışmalara bağlı olarak e-belge ve e-belge yönetimi alanında çalışmalar yapılmıştır. Kandur'un da belirttiği gibi $(2011$, s. 6) bu anlamda yapılan ilk faaliyet; 2003'te e-Dönüşüm Türkiye İcra Kurulu'nun oluşturulması ve hemen ardından hazırlanan eylem planı ile eDönüşüm Türkiye Projesi 2005 Yılı eylem planının yayınlanması olmuştur.

2005 yılında "EBYS Kriterleri Referans Modeli (v.1.0)" Devlet Planlama Teşkilatı'nn koordinatörlüğünde bir toplantı ile kamu kurumlarına sunulmuştur. Ardından referans model geliştirilmiş ve 2006'da (v.2.0) olarak yayınlanmıştır. Ayrıca yine 2006 yılında model, standarta dönüştürülerek Türk Standartları Enstitüsü’ne sunulmuş ve 2007'de “TS 13298Elektronik Belge Yönetimi Standardı" yayınlanmıştır. Ardından bu standardın kullanımı 2008/16 sayılı ve Elektronik Belge Standartları konulu Genelge ile tüm kamu kurumları için zorunlu hale getirilmiştir (Kandur, 2011, s. 6).

Tüm kamu hizmetlerini tek bir noktadan web tabanlı olarak sunma projesi olan ve 18 Aralık 2008 tarihinde hizmete giren e-Devlet Kapısı'nda (turkiye.gov.tr) yillar itibariyle sunulan hizmetlerin ve sisteme kayıt yaptıranlar sürekli artmıştır. E-Devlet Kapısı faaliyete geçtiği 2008 y1l itibariyle 22 hizmet kalemiyle 10.000, 2010 y1lı sonunda 246 hizmet kalemiyle 1.950.000 (Devlet Planlama Teşkilatı, 2011, s. 76-78) ve 2018 Mayıs ayı itibariyle 454 kurumun 3252 hizmet kaleminde toplam 37.660.000 kullanıcıya hizmet vermektedir (https://www.turkiye.gov.tr). Görüldüğü gibi sistemde sunulan hizmetlerin ve bu hizmetleri kullanabilmek için sisteme kayıt yaptıranların sayısında yıllar içinde ciddi bir artış olduğu görülmektedir.

Birleşmiş Milletler (BM) tarafindan dönem dönem yapılan ve ülkelerin E-Devlet hazırlık aşamaları ve süreçlerinin değerlendirildiği "E-Government Readiness Index" raporuna göre Türkiye'nin y1llar içindeki durumu Tablo 8'de verilmiştir. Türkiye'de E-Devlet hizmetleri çoğaldıkça, dünyadaki E-Devlet uygulamaları sıralamasındaki yerinin de değiştiği görülmektedir. 
Tablo 2. E-Devlet Hazırlık İndeksi

\begin{tabular}{|l|l|l|l|}
\hline Yillar & & Puan & Siralama \\
\hline 2003 & & 0.506 & 49 \\
\hline 2004 & \multirow{4}{*}{ Türkiye } & 0.4892 & 57 \\
\hline 2005 & & 0.4960 & 60 \\
\hline 2008 & & 0.4834 & 76 \\
\hline 2010 & & 0.4780 & 69 \\
\hline 2012 & & 0.5281 & 80 \\
\hline 2014 & & 0.5443 & 71 \\
\hline 2016 & & 0.6271 & 60 \\
\hline
\end{tabular}

Kaynak: Global E-Government Survey (2003;2004;2005;2008;2010;2012;2014;2016)

Tabloya göre Türkiye, 2003 yılında 0.506 puanla 49. sirada iken, 2016'da 0.6271 puanla 60 . sırada yer almıştır. Türkiye'nin, gerek puan gerekse sıralamalarda genellikle orta sıralarda bulunduğu görülmektedir. Bu durum bize; E-Devlet çalışmalarında giderek artan bir şekilde çalışmalar yapıldığını, fakat diğer ülkeler ile karşılaştırıldığında yeteri kadar ilerleme sağlanamadığını göstermektedir. Küresel E-Devlet Araştırma sıralamasında 2016 yılında ilk sırayı alan devlet 1.000 puanla Birleşik Krallık'tır. (United Nations E-Government Survey, 2016h, s. 175).

Belge Yönetim Sistemi alanında ise Ankara Üniversitesi tarafindan hayata geçirilen Belge Yönetimi ve Arşiv Sistemi (BEYAS) önemli bir proje olarak karşımıza çıkmaktadır. Sistemin, Ankara Üniversitesi'nde yürütülmekte olan belge işlemlerinin, belge yönetimi ilkelerine göre yürütülmesini sağlamak ve üniversitelere rehber olacak bir model oluşturma amacı vardır. Proje; üniversite idari ve akademik birimlerinde yapılan iki yıllık bir çalışma sonucunda (2008-2010) tamamlanmıştır. Üniversitedeki bu süreç Devlet Arşivleri Genel Müdürlüğü (DAGM) ve TÜBİTAK tarafından da desteklenmiştir. Fiziksel belgeler için altyapının oluşturulmasından hemen sonra, 2011 yılında TÜRKSAT A.Ş. ile işbirliği yapılarak bir EBYS yazılımı geliştirilmeye başlanmış ve e-BEYAS 2013 yılında kullanıma hazır hale getirilmiştir. Bu sayede Ankara Üniversitesi'ndeki iş süreçlerine yönelik olarak her çeşit belge ve dokümanın korunması sonucu organizasyonel yapıya uyumlu bir çatı model kapsamında güvenli bir biçimde üretimi, kayıt altına alınması ve arşivlenmesi sağlanmıştır (http://beyas.ankara.edu.tr/gecis duyurusu/).

Maliye Bakanlığı Gelir İdaresi Başkanlığı tarafından başlatılan E-Tebligat sistemi projesi, bu alandaki ilgili belgelerin elektronikleşmesine diğer bir örnek olarak verilebilir. Önceleri fiziksel ortamda iletilen tebligatlar, 1 Nisan 2016 tarihinden itibaren elektronik ortamda yapılmaya başlanmıştır. Buna göre vergi dairesi tarafından elektronik olarak imzalanan belge, dijital ortama gönderilecek, daha sonra mükelleflerin cep telefonlarına veya e-posta adresine bilgilendirme mesaj1 iletilecektir (http://www.gib.gov.tr/e-Tebligat).

Mükellefler de Gelir İdaresi Başkanlığı'nın web sitesinden e-tebligat sistemine giriş yaparak tebligatı görüntüleme ve belgenin çıktısını alabilmektedir. Ayrıca 2016 yılının Mayıs ayından itibaren gerçek kişilere yönelik yapılan e-tebligatlar, e-Devlet Kapısı'ndan da görülebilmektedir (http://www.gib.gov.tr/e-Tebligat). Aşağıdaki şekilde E-Tebligat süreci verilmiştir. 

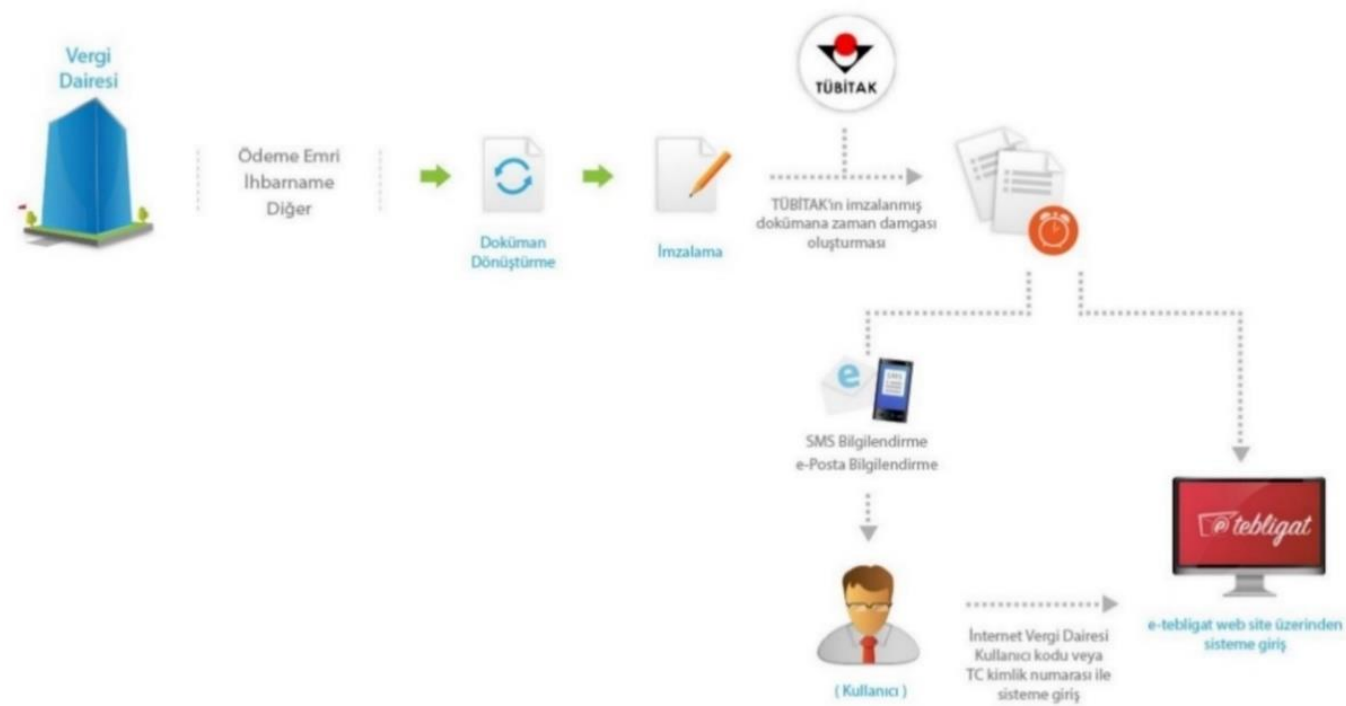

Şekil 1: E-Tebligat Süreci

Kaynak: http://www.gib.gov.tr/e-Tebligat

\section{Sakarya Üniversitesi'nde EBYS Çalışmaları}

Kamu kurum ve kuruluşlarındaki resmi yazışma süreçleri çoğunlukla zaman alıcı faaliyetler olarak bilinmektedir. $\mathrm{Bu}$ olumsuz etkileri ortadan kaldırmak amacıyla birçok kamu kurumunda gerek kurum içi gerekse kurum dışı yazışmaların elektronik ortamda daha hızlı ve etkin yürütülebilmesi için elektronik belge yönetim sistemi (EBYS) uygulamalarına geçilmiştir.

Sakarya Üniversitesi'nde kurum içi yazışmalarda paraf ve imza sürecinin hızlandırılması, üretilen evrakların ilgili kurumlara daha hızlı ulaştırılması, kurumsal iş süreçlerinin hızlandırılması, veri ve bilgiye sağlıklı ve hızlı erişim sağlanması, kırtasiye masraflarının azaltılması ve personel kaynaklarının etkin kullanılması gibi amaçlarla EBYS çalışmaları başlatılmıştır. Bu doğrultuda Şubat 2013 tarihinde Genel Sekreterlik ve Bilgi İşlem Daire Başkanlığı koordinatörlüğünde EBYS'ye yönelik altyapı çalışmaları başlatılmış ve Haziran 2013 tarihi itibariyle de önce Rektörlük bünyesinde, Eylül 2013 tarihinden beri tüm üniversite birimlerinde EBYS uygulaması kullanılmaya başlanmıştır. Buna ek olarak idari yöneticiler ile öğretim üyelerinin tamamı e-imza kullanarak belge imzalama işlemlerini sürdürmektedirler. PTT Kayıtlı Elektronik Posta (KEP) servisi ve e-yazışma paketi entegrasyonu ile EBYS üzerinden tüm kamu kurumlarıyla resmi belge alışverişi de başlamış bulunmaktadir.

Yapılan birçok çalışmada insanların teknoloji kullanımında ve algılamalarında farklılıklarının olduğu belirtilmektedir. Bu çalışmada Sakarya Üniversitesi'nde belge oluşturma, onaylama, saklama ve dağıtım gibi işlemlerin tamamının elektronik ortama taşınması amacıyla kurulan EBYS'nin, üniversite personeli tarafından ne ölçüde kabul edildiği araştırılmak istenmiştir. 


\section{Teknolojinin Kabulünü İnceleyen Teoriler}

Literatürde kişilerin bilgisayarları veya yeni teknolojileri kabulü sıkça tartışılan konulardandır. Ayrıca araştırmacılar, kullanım davranışına yol açan inanç ve tutumları etkileyen dış faktörleri sosyoloji ve psikoloji disiplinlerinden hareketle incelemişlerdir. Kişilerin teknoloji kullanım davranışlarını nelerin belirlediğini sosyal psikoloji alanından niyet modelleri ile açıklamaya çalışmışlardır. (Şıklar vd., 2015, s.102; Esen ve Büyük, 2014, s. 315).

Bu anlamda ilk teori, Fishbein ve Ajzen (1975) tarafından geliştirilen Sebepli Faaliyetler Teorisi'dir (Theory of Reasoned Action-TRA). Bir diğer önemli teori, Rogers (1983) tarafından öne sürülen Yeniliklerin Yayılması Teorisi'dir (Diffusion of Innovations-DOI). Ayrıca yine Ajzen (1988) tarafından TRA'nın daha gelişmiş modeli olarak geliştirilen Planlı Davranışlar Teorisi (Theory of Planned Behavior-TPB) de önem arzetmektedir. Hem TRA'yı hem de TPA'yı temel alarak Davis (1989) tarafindan oluşturulan Teknoloji Kabul Modeli (Theory of Technology Acceptance Model-TAM) ise Yönetim Bilişim Sistemleri literatüründe sık kullanılan bir model haline gelmiştir. (Turan ve Çolakoğlu, 2008, s. 111112). Tablo 3 'te teknoloji kabulüne kaynak oluşturan teoriler yer almaktadır.

Tablo 3. Teknolojinin Kabulü ve Kullanımı ile İlgili Teori ve Modeller

\begin{tabular}{|c|c|}
\hline Teori & Teorisyen \\
\hline Yeniliğin Yayılmas1 Teorisi (DOI) & Rogers (1962) \\
\hline Sebepli Faaliyetler Teorisi (TRA) & Fishbein ve Ajzen (1975) \\
\hline Planlı Davranışlar Teorisi (TPB) & Ajzen (1988) \\
\hline Teknoloji Kabul Modeli (TAM) & Davis (1989) \\
\hline Teknoloji Kabul Modeli 2 (TAM2) & Venkatesh ve Davis (2000) \\
\hline Teknoloji Kabul Modeli 3 (TAM3) & Venkatesh ve Bala (2008) \\
\hline
\end{tabular}

Çalışmada, kullanıcıların EBYS'yi benimsemesinde etkili olan faktörleri açıklamaya yönelik olarak oluşturulan araştırma modeli; Ajzen ve Fishbein tarafindan önerilen Sebepli Faaliyetler Teorisi, Davis tarafindan geliştirilen Teknoloji Kabul Modeli ve Venkatesh ve Davis tarafından geliştirilen Teknoloji Kabul Modeli 2'de yer alan bazı değiş̧kenlerin ilişskisel bir düzlemde ortaya konulmasıyla modellenmiştir. Böylece; araştırma modeline yönelik iş ile ilgililik, deneyim, algılanan fayda, algılanan kullanım kolaylığı ve niyetin etkileri tahmin edilmeye çalışılmıştır. Şekil 2'de araştırma modeli gösterilmektedir.

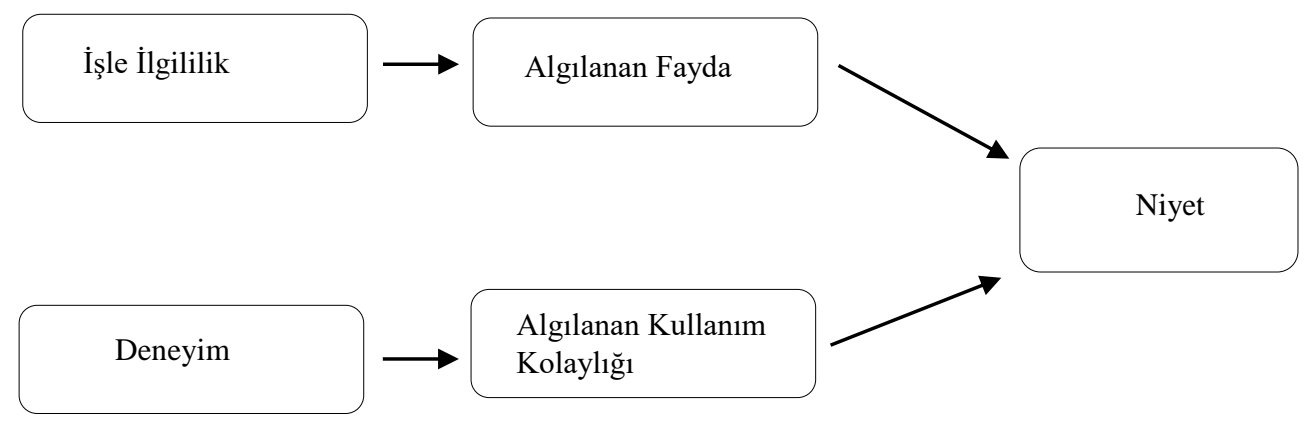

Şekil 2: Araştırma Modeli

Araştırma, Sakarya Üniversitesi akademik ve idari personelinin EBYS kullanımının benimsenmesindeki temel etki ve nedenleri ortaya çıkarmayı hedeflemektedir. $\mathrm{Bu}$ etki ve 
nedenleri belirlemek amacıyla oluşturulan araştırma modelinde beş değişken özelinde araştırma soruları sorulmuş ve hipotezler geliştirilmiștir. Bu değişkenler arasındaki ilişkilerin varlığını ve yönünü ölçümlemek için geliştirilen 4 hipotez teste tabi tutulacaktır. $\mathrm{Bu}$ hiopotezler; $\mathrm{H}_{1}$ : İşle ilgililik, algılanan fayda üzerinde pozitif bir etkiye sahiptir; $\mathrm{H}_{2}$ : Deneyim, algılanan kullanım kolaylığı üzerinde pozitif bir etkiye sahiptir; $\mathrm{H}_{3}$ : Algılanan fayda, EBYS kullanımına yönelik niyet üzerinde pozitif bir etkiye sahiptir; $\mathrm{H}_{4}$ : Algılanan kullanım kolaylığı, EBYS kullanımına yönelik niyet üzerinde pozitif bir etkiye sahiptir.

\section{Yöntem}

Araştırmada nicel yöntemlerden faydalanılmıştır. Sosyal bilimlerde yapılan araştırmalarda veri toplamak ve yorumlarda bulunmak için en yaygın yol sorular sormaktır. Katılımcılara sorular sormak denince akla anketler gelir (Gürbüz ve Şahin, 2015, s. 185). Örneklem seçiminde olasılığa dayalı olmayan örnekleme yöntemlerinden kolayda örnekleme ve amaçlı örnekleme yöntemi eş zamanlı olarak kullanılmıştır. Çalışmaya adapte edilerek hazırlanan anket; Sakarya Üniversitesi'nde görev yapan onbeşi akademisyen, otuzbeşi EBYS kullanma yetkinliğine sahip idari personel toplam elli kişiye ön çalışma kapsamında uygulanmıştır. $\mathrm{Bu}$ ön uygulamanın nedeni; soruların anlaşı1ır olup olmadığının kontrol edilmesi, çalışma içeriğine olan uygunluğunun tespiti ve personelin kurumsal olarak sorulara cevap verip veremeyecekleridir. Ön uygulama sonucunda ankete verilen cevaplarda herhangi bir eksiklik ve tutarsızlığa rastlanmadığı ve yapılan ön analizlerde uyumlu sonuçlar çıtığı için anketin revize edilmesine gerek olmadığ 1 kanısına varılmıştır. Online anket, kullanıcıların elektronik posta adreslerine gönderilmek suretiyle yapılmış ve veriler toplanmıştır. Araştırma modelindeki değişkenlerin ankete alınma nedenleri aşağıda verilmiştir:

- İşle İlgililik (Venkatesh ve Davis, 2000): Bireyler, farklı çıkar algılarına sahiptir ve yapılan işlerin farklılığı nedeniyle, teknolojiden çeşitli kazanım ve fayda beklerler. Ayrıca bireyler, ihtiyaç duydukları teknolojiyi seçme noktasında dış kaynaklardan gelen bilgilere de maruz kalırlar. Personelin, sorumlusu olarak yaptığ 1 işlerin bu noktada EBYS ile uyumlu olması, uygulamanın benimsenmesine yönelik önemli bir nokta olarak karşımıza çıkmaktadır.

- Deneyim (Venkatesh ve Davis, 2000): Deneyim, bireyin teknolojiyi kullanmasina yönelik olarak genel memnuniyet derecesini ifade eder. Ayrıca deneyim, bireysel farklılıkların belirlenmesinde önemli kabul edilmiştir. Örneğin, benzer bir teknolojiyle elde edilen deneyimlerin, bir kişinin benimseme kararındaki tutumunu etkileyen önemli bir faktör olduğu tespit edilmiştir (Dabholkar, 1996, s. 40). Kullanıcıların teknolojik bilgi ve beceri durumu ile bilişim teknolojileri deneyimi, EBYS kullanımını etkileyecek olan etkenlerin başında gelmektedir.

- Algılanan Fayda (Davis, 1985): Teknoloji kabul modellerinde algilanan fayda, başlıca faktörlerden birisidir. Kullanıcının belirli bir sistemi kullanarak kendi işini veya yaşam performansını artıracağı öznel olasılık olarak tanımlanır. EBYS'nin benimsenmesinde güçlü bir açıklayıcı gösterge olmaktadır.

- Algılanan Kullanım Kolaylığı (Davis, 1985): Kullanıcının bilgi teknolojisini kabul etmesi ve kullanımındaki niyetinin oluşmasında, algılanan kullanım kolaylığının önemi büyüktür. Bireyin, bir sistemi kolayca kullanması noktasında inanç düzeyi yükseldikçe, sistem kullanımının iş performansını daha verimli hale getireceğine olan inanç düzeyinin de aynı oranda artığı söylenebilir. EBYS'nin algılanan kullanım kolaylığı, etkili bir eğitim sürecine, iş ve işlemlerde karşılıklı diyolağa ve 
kullanıma yönelik yeniliklerin uygulanmasına da bağlıdır.

- Niyet (Fishbein ve Ajzen, 1975): Niyet; kişinin davranışının doğrudan belirleyicisidir. $\mathrm{Bu}$ nedenle niyet bileşeni, davranış değişikliği için önemli bir amaçtır çünkü bu, kişinin bir eylemi gerçekleştirme niyetini etkileyebilir. EBYS kullanım niyeti, araştırma modelindeki değişkenlere, özellikle de algılanan kullanım kolaylığı ve algılanan faydaya bağlıdır.

\subsection{Bulgular}

Araştırmaya katılan çalışanların demografik özellikleri Tablo 5 'te gösterilmiştir. Buna göre ankete katılanların \%2.7'si 18-24, \%42.1'i 25-34, \%28.8'i 35-44, \%18.5'i 45-54, \%5.2'si 5560 ve $\% 2.7$ 'si $60+$ üzeri yaştadır. Ankete katılanların çoğunlukla 25-34 yaş grubuna ait oldukları tespit edilmiştir. Bununla birlikte personelin \%55.8'i erkek olup toplamda 184 kişi, \%44.2'si kadın olup toplamda ise 146 kişiden oluşmaktadır. Çalışmada, katılımcıların eğitim durumlarına bakıldığında ise lisans mezuniyeti 110 kişi ile en fazla oranda temsil edilmektedir. Katılımc1ların \%4.2'si lise, \%10.6'sı önlisans, \%33.3'ü lisans, \%30.3'ü yüksek lisans ve \%21.5'i doktora eğitimi almıştır.

Tablo 5. Demografik Faktörler

\begin{tabular}{|l|c|c|c|}
\hline Değişkenler & \multicolumn{3}{|c|}{} \\
\hline \multirow{4}{*}{ Yaş } & Aralık & Frekans (N) & Yüzde (\%) \\
\cline { 2 - 4 } & $18-24$ & 9 & 2.7 \\
\cline { 2 - 4 } & $25-34$ & 139 & 42.1 \\
\cline { 2 - 4 } & $35-44$ & 95 & 28.8 \\
\cline { 2 - 4 } & $45-54$ & 61 & 18.5 \\
\cline { 2 - 4 } & $55-60$ & 17 & 2.2 \\
\hline Cinsiyet & $60+$ & 9 & 55.8 \\
\cline { 2 - 4 } & & & 44.2 \\
\cline { 2 - 4 } & Kadin & 146 & 4.2 \\
\hline Eğitim Durumu & Erkek & 184 & 10.6 \\
\cline { 2 - 4 } & & & 33.3 \\
\cline { 2 - 4 } & Lise & 14 & 30.3 \\
\cline { 2 - 4 } & Önlisans & 110 & 21.5 \\
\cline { 2 - 4 } & Lisans & 100 & 45.8 \\
\cline { 2 - 4 } & Yüksek Lisans & 71 & 54.2 \\
\hline Personel Türü & Doktora & & 100 \\
\hline Toplam & Akademik & 151 & \\
\cline { 2 - 4 } & İdari & 330 & \\
\hline
\end{tabular}

Çalışmada kullanılan ölçeklerin güvenirliği Cronbach Alpha katsayısı yardımıyla sınanmıştır. Alfa katsayısı bir örneklem üzerinde tek seferde uygulanan her hangi bir ölçeğin güvenirliliğinin sınanmasında yaygın olarak kullanılan bir istatistiktir (Tavşancıl, 2010). Çalışmada kullanılan gizil değişkenlere ilişkin SMARTPLS programıyla hesaplanan Alpha katsayıları aşağıda verilmektedir. 
Tablo 6. Faktörlerin Katsayıları

\begin{tabular}{|l|c|c|c|}
\hline \multicolumn{1}{|c|}{ Faktörler } & Cronbach's Alpha & İfade Sayısı & Ortalama Varyans \\
\hline Algılanan Fayda & 0.966 & 6 & 0.854 \\
\hline Algılanan Kullanım Kolaylığı & 0.938 & 5 & 0.800 \\
\hline Deneyim & 0.420 & 2 & 0.619 \\
\hline Niyet & 0.933 & 3 & 0.882 \\
\hline İşle İlgililik & 0.927 & 3 & 0.873 \\
\hline
\end{tabular}

Yukarıda Tablo 6'da verilen alfa katsayılarına göre değerler 0.42 ile 0.97 arasında değişmektedir. Deneyim ölçeğine ilişkin alfa değeri 0.42 olarak hesaplanmıştır. Bu değer kritik değer olan 0.50 kabul edilebilir eşiğin altındadır. Diğer ölçekler 0.90 ve yukarısında olduğundan yüksek düzeyde güvenirliliğe sahip oldukları söylenebilir. Ölçeklerin açıklanan varyans oranlarına bakılırsa en yüksek 0.88 ve en küçük 0.62 değerlerinin elde edildiği görülmektedir. Buna göre, ölçeklerin açıklanan varyans oranları 0.50 ve yukarısında olduğundan ölçeklerde yer alan ifadelerin değişkenliği $\% 50$ ve yukarısında açıkladığı söylenebilir.

Çalışmada gizil değiş̧kenler arasındaki ilişkinin analizi için kısmi en küçük kareler yapısal eşitlik modeli (PLS-SEM: Partial Least Square Strutural Equation Modeling) kullanılmıştır. PLS-SEM Ringle, Wende ve Will tarafından 2005 yılında geliştirilmiştir (Wong, 2013). PLS-SEM yaklaşımı verilerin dağılımına ilişkin herhangi bir varsayımda bulunmamaktadır. Ayrıca PLS-SEM küçük örneklemlerde de düzgün çalışmaktadır. Gizil değişkenler arasındaki okların sayısının modelde dört olması durumunda minimum örnek sayısının 65 olması yeterli görülmektedir (Wong, 2013). Çalışmada kullanılan verilere ilişkin PLS-SEM analizi sonuçlarına ilişkin yol grafiği aşağıda verilmektedir.

Şekil 3’te gösterilen PLS yol grafiğinde her bir gizil değişkenin daireler ile simgelendiği görülmektedir. Dairelerin içindeki her bir değer gizil değişkenin diğer kendisini etkileyen gizil değişkenlerce ne kadar açıklandığının $\mathrm{R}^{2}$ ölçüsünü vermektedir. $\mathrm{Bu}$ değerlere göre, Niyet dışsal gizil değişkeninin \%58.6'sı Algılanan Fayda ve Algılanan Kullanım Kolaylığı gizil değişkenleriyle açılanmaktadır. Benzer şekilde Algılanan Fayda dışsal gizil değişkeninin \%45.7'si İşle İlgililik gizil değişkeni tarafından açıklanmaktadır. Algılanan Kullanım Kolaylığ 1 dışsal gizil değişkeninin ise \%11.2'si ise içsel Deneyim gizil değişkeni ile açıklanmaktadır.

Modelde Niyet gizil değişkeni üzerinde en büyük etkiye Algılanan Fayda gizil değişkeni sahiptir (0.515), onu Algılanan Kullanım Kolaylığı (0.291) takip etmektedir. İşle ilgililik, Algılanan Fayda gizil değişkenini pozitif yönde etkilerken Deneyim gizil değişkeni Algılanan Kullanım Kolaylığının gizil değişkenini negatif yönde etkilemektedir. Katsayıların t değerlerine bakıldığında bütün katsayıların 0.05 anlamlılık düzeyinde sıfırdan farklı olduğu söylenebilir. 


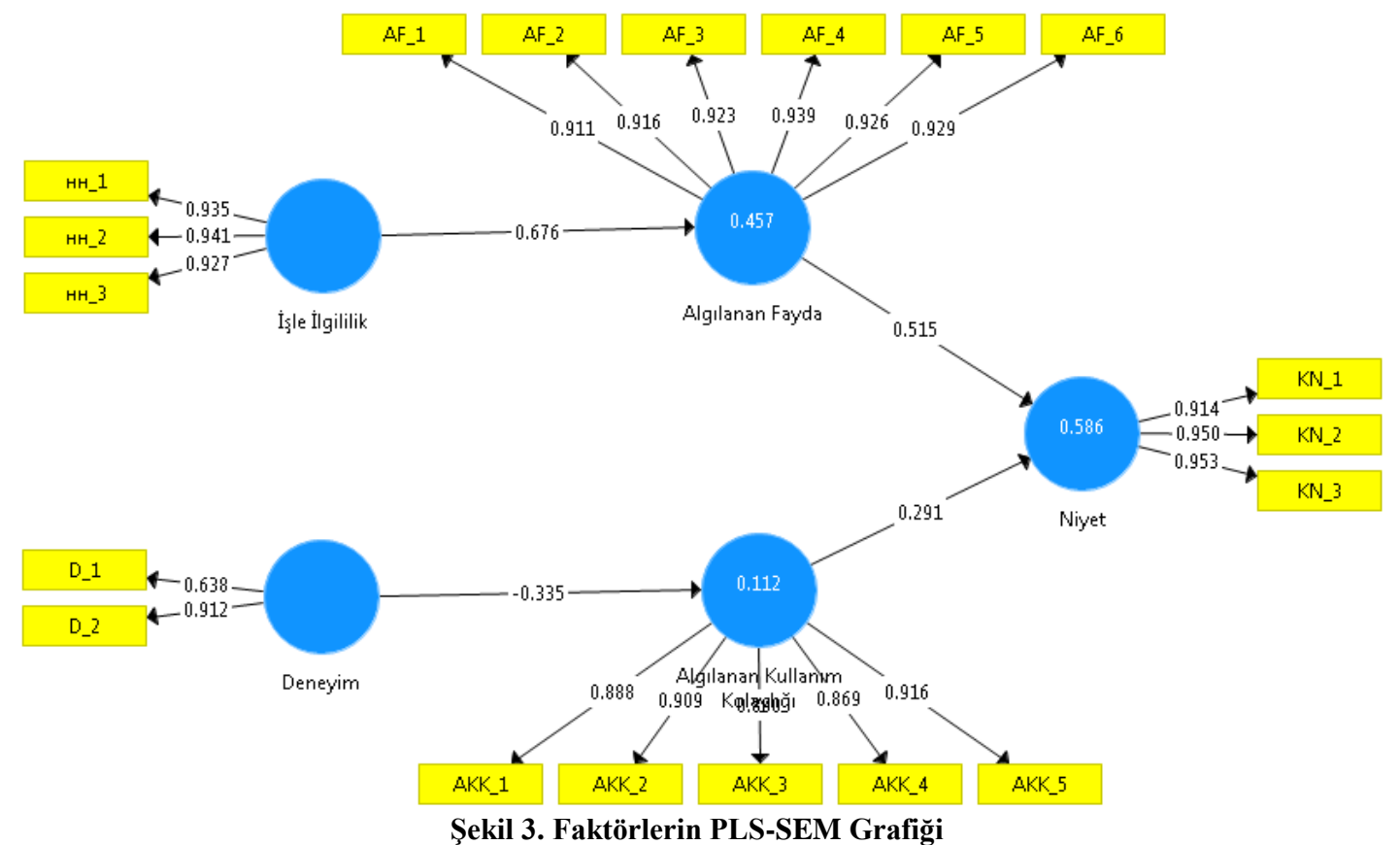

Tablo 7. İfadelerin Katsayı ve t Değerleri

\begin{tabular}{|c|l|c|c|}
\hline Hipotez & \multicolumn{1}{|c|}{ İfade } & Katsayı & t değeri \\
\hline Hipotez 1 & $\begin{array}{l}\text { İşle ilgililik, algılanan fayda üzerinde olumlu bir etkiye } \\
\text { sahiptir }\end{array}$ & 0.676 & 16.39 \\
\hline Hipotez 2 & $\begin{array}{l}\text { Deneyim, algılanan kullanım kolaylığı üzerinde pozitif bir } \\
\text { etkiye sahiptir }\end{array}$ & -0.335 & 7.02 \\
\hline Hipotez 3 & $\begin{array}{l}\text { Algılanan kullanım kolaylığı ile EBYS kullanımına yönelik } \\
\text { niyet ile pozitif ilişkilidir }\end{array}$ & 0.291 & 3.75 \\
\hline Hipotez 4 & $\begin{array}{l}\text { Algılanan fayda ile EBYS kullanımına yönelik niyet ile } \\
\text { pozitif ilişkilidir }\end{array}$ & 0.515 & 6.41 \\
\hline
\end{tabular}

Yukarıda Tablo 7'den de görüleceği üzere araştırmada yer alan hipotezlerden yalnızca deneyim gizil değişkeninin algılanan kullanım kolaylığını pozitif yönde etkilediği doğrulanamamıştır. Buna göre, İşle ilgililik Algılanan fayda üzerinde pozitif yönde etkilidir, Algılanan kullanım kolaylığı ve Algılanan Fayda doğrudan Niyet üzerinde etkilidir. İşle ilgililik ise dolaylı yoldan niyet üzerinde etkilidir.

\section{Sonuç ve Değerlendirme}

Bilgi teknolojileri alanında yaşanan hızlı gelişmeler, tüm süreçlerde iş yapma biçimi derinden etkilenmiştir. Kamu kurum ve kuruluşları da, bilgi teknolojilerini kullanarak süreçlerini elektronikleştirmeye başlamış, bunun sonucunda optimum faydayı hedefleyen yeni tür kamusal yönetim mantığı doğmuştur. Bu mantıkta, bilgilerin doğru, hızlı ve güvenilir olması gerektiğinden buna uygun projeler geliştirilmiştir. Günümüzde bilgi, gerek bireyler gerekse organizasyonlar açısından oldukça önemli bir kavram haline dönüşmüş durumdadır. Stratejik bir kaynak durumuna gelen, kurumsal ve bireysel kararların temelini 
oluşturan ve üretim sisteminin en önemli girdisi ve ürünü haline gelen bilginin çok boyutlu bir kavram olduğunu, değişik bağlamlarda değişik amaçlar için farklı biçimlerde kullanılabildiğini söylemek mümkündür (Baytekin, 2012, s. 14). EBYS yazılımları bu amaçlarla geliştirilen örneklerden sadece birisidir. Çalışmada, Sakarya Üniversitesi'nde kullanılmakta olan EBYS yazılımının, çalışanlar tarafından kabul edilebilirliğine yönelik bir araştırma yapılmıştır. Çalışanların EBYS kullanım düzeylerini ölçmek için işle ilgililik, deneyim, algılanan fayda, algılanan kullanım kolaylığı ve niyet faktörleri belirlenmiş ve çalışmaya adapte edilen ankete 330 çalışan tarafından cevap verilmiştir.

Türkiye'de EBYS'nin benimsenmesinin Teknoloji Kabul Modeli temelinde araştırıldığ çalışma sayısı oldukça azdır. Yapılan bazı çalışmalarda (Eren ve Kaya, 2016) algılanan fayda ve algılanan kullanım kolaylığının davranışsal tutum üzerinde anlamlı bir etkisinin olduğu görülmüştür. Aynı şekilde algılanan fayda ve davranışsal tutumun da kullanıcı niyetini belirlemede etki ettiği görülmüştür. İşin uygunluğu ve algilanan kolaylığın algılanan fayda üzerinde anlamlı bir etkisi varken kişisel normun algılanan kullanışl1lık üzerinde herhangi bir anlamlı etkisi bulunamamıştır. Davranışsal tutumun da kullanıcı niyetleri üzerinde anlamlı bir etki oluşturduğu da görülmüştür. Bir diğer çalışmada da (Esgin, 2015) e-dönüşüm modelinin kullanıcılar tarafından benimsendiği ancak modelin geliştirilmesi gereken yönleri olduğu anlaşılmıştır.

Çalışmada, Deneyim ölçeği hariç $(0,42)$ diğer ölçekler 0.90 ve yukarısında olduğundan yüksek düzeyde güvenirliliğe sahip oldukları görülmektedir. Niyet gizil değişkeninin \%58.6's1 Algılanan Fayda ve Algılanan Kullanım Kolaylığı gizil değişkenleriyle açıklanmaktadır. Benzer şekilde Algılanan Fayda gizil değişkeninin \%45.7'si İşle İlgililik gizil değişkeni tarafından açıklanmaktadır. Algılanan Kullanım Kolaylığı dışsal gizil değişkeninin ise \%11.2'si ise içsel Deneyim gizil değişkeni ile açıklanmaktadır.

Modelde Niyet gizil değişkeni üzerinde en büyük etkiye Algılanan Fayda gizil değişkeni sahiptir (0.515), onu Algılanan Kullanım Kolaylığı (0.291) takip etmektedir. İşle ilgililik, Algılanan Fayda gizil değişkenini pozitif yönde etkilerken Deneyim gizil değişkeni Algılanan Kullanım Kolaylığının gizil değişkenini negatif yönde etkilemektedir. Araştırmada yer alan hipotezlerden yalnızca deneyim gizil değişkeninin algılanan kullanım kolaylığını pozitif yönde etkilediği doğrulanamamıştır. Başka bir deyişle deneyim faktörü, algılanan kullanım kolaylığını açıklayamamaktadır. 


\section{KAYNAKÇA}

BAYTEKİN, E. P. (2012). Bilgi Yönetimi: Halkla İlişkiler Açısından Bir Değerlendirme. İzmir: Ege Üniversitesi, s. 166.

CORNU, J. M. (ed.). (1997). Guidelines on Best Practices for Using Electronic Information: How to Deal with Machine-Readable Data and Electronic Documents (Updated and enlarged edition). European Communities, Italy.

DAVIS, F. (1985). A Technology Acceptance Model for Empirically Testing New End-User Information Systems. Doktora Tezi. MIT Sloan School of Management, Cambridge MA.

Devlet Planlama Teşkilatı. (2011). Bilgi Toplumu İstatistikleri, Ankara: Devlet Planlama Teşkilatı, Yayın No:2826.

EREN, A. ve KAYA, M. D. (2016). Üniversite Çalışanlarının Elektronik Belge Yönetim Sistemini Kullanma Niyetlerinin Teknoloji Kabul Modeli ile İncelenmesi. Yönetim Bilişim Sistemleri Dergisi, 1(3), 157-168

ESEN, M. ve BÜYÜK, K. (2014). Teknoloji Kabul Modeli Bağlamında Elektronik Belge Yönetim Sisteminin İncelenmesi: Yükseköğretim Kurulu Örneği. Dumlupınar Üniversitesi Sosyal Bilimler Dergisi, 42, 313-326.

ESGIN, E. (2015). Kamuda Kurumsal Bilgi Yönetimi İçin E-Dönüşüm Modeli: Marmara Üniversitesi Elektronik Belge Yönetim Sistemi Örneği. Doktora Tezi, Marmara Üniversitesi.

European Commission. (2008). MoReq2 Specification: Model Requirements for the Management of Electronic Records (Update and Extension). Nisan 2, 2018 tarihinde http://www.interpares.org/display_file.cfm?doc=ip2_dissemination_rep_moreq2_2008 .pdf adresinden erişildi.

FISHBEIN, M. and AJZEN, I. (1975). Belief, Attitude, Intention and Behavior: An Introduction to Theory and Research. Addison Wesley, Reading, MA.

GÜRBÜZ, S. ve ŞAHIN, F. (2015). Sosyal Bilimlerde Araştırma Yöntemleri: FelsefeYöntem-Analiz. Seçkin Yayıncılık.

International Organization for Standartization. (2001). ISO 15489-1: 2001 Information and Documentation.

KANDUR, H. (2011). Türkiye'de Kamu Kurumlarında Elektronik Belge Yönetimi: Mevcut Durum Analizi ve Farkındalığın Artırılması Çalışmaları. Bilgi Dünyası. 2011, 12(1) ss. $2-12$.

KANDUR, H. (2006). Elektronik Belge Yönetimi Sistem Kriterleri Referans Modeli v.2.0. Devlet Arşivleri Genel Müdürlügü. Mayıs 21, 2018 tarihinde https://goo.gl/VEPe3z adresinden erişildi.

ODABAŞ, H. (2008). Elektronik Belge Düzenleme Yaklaşımları ve Türkiye'de E-Devlet Uygulamalarında Elektronik Belge Yönetimi. Atatürk Üniversitesi Sosyal Bilimler Enstitüsü Dergisi, 12 (2): 121-142. 
ŞIKLAR, E., TUNALI, D. ve GÜLCAN, B. (2015). Mobil İnternet Kullanımının Benimsenmesinde Yakınsama Faktörüyle Teknoloji Kabul Modeli. Anadolu Üniversitesi Sosyal Bilimler Dergisi, 15(2), 99-110.

TAMTÜRK, E. (2015). Kamu Yönetiminde Elektronik Belge Yönetim Sistemi. Muş Alparslan Üniversitesi Sosyal Bilimler Dergisi, Cilt: 5, Say1: 3, ss. 851-863.

TAVŞANCIL, E. (2010). Tutumların Ölçülmesi ve SPSS ile Veri Analizi. Nobel Yayıncılık.

TURAN, A.H., ÇOLAKOĞLU, B.E. (2008). Yükseköğrenimde Öğretim Elemanlarının Teknoloji Kabulü ve Kullanımı: Adnan Menderes Üniversitesinde Ampirik Bir Değerlendirme. Doğuş Üniversitesi Dergisi, 9(1), 106-121.

United Nations. (2003,2004,2005,2008,2010,2012,2014,2016). Global E-Government Survey. UN Department of Economic and Social Affairs.

VENKATESH, V. and DAVIS, F. (2000). A Theoretical Extension of the Technology Acceptance Model: Four Longitudinal Field Studies. Institute for Operations Research and the Management Sciences, 46, pp. 186-204.

WONG, K. K. (2013). Partial Least Squares Structural Equation Modeling (PLS-SEM) Techniques Using SmartPLS. Marketing Bulletin, 2013, 24, Technical Note 1.

http://beyas.ankara.edu.tr/gecis duyurusu, 30.05.2018 tarihinde erişildi.

https://www.turkiye.gov.tr, 30.05.2018 tarihinde erişildi.

http://www.gib.gov.tr/e-Tebligat 28.04.2018 tarihinde erişildi.

https://archives.un.org/content/glossary-recordkeeping-terms 28.05.2018 tarihinde erişildi. 